\title{
Regional Conflict, Ceramic Senescence, and Pawnee Raw Material Choice in the Late Contact Era
}

\author{
Margaret E. Beck (D, Richard L. Josephs, Lauren W. Ritterbush, and Donna C. Roper ${ }^{\dagger}$
}

\begin{abstract}
Here, we consider the last decades of ceramic manufacture among the Pawnee in the Central Great Plains, using petrographic analysis to explore raw material availability and use at the Kitkahahki Town site (14RP1). Historical documents reveal tremendous regional pressures and conflicts in the Kitkahahki Town area during its occupation in the late eighteenth and early nineteenth centuries - processes that could have altered or restricted the movement of women outside village boundaries. Contact-era Pawnee pottery from Kitkahahki Town exhibits atypical paste textures, atypical inclusions, or both. At least one potter used atypical materials available immediately adjacent to the village, which suggests that ceramic raw material collection was at least occasionally adjusted to reduce risk. Petrographic analysis contributes to our understanding of Indigenous communities in colonial settings, particularly to questions of technological change and landscape use when both were intensely negotiated and rapidly changing.
\end{abstract}

Keywords: Great Plains, Pawnee, ceramics, petrography, colonial period

Aquí, consideramos las últimas décadas de la manufactura de cerámica entre los pawnee en las Great Plains centrales, usando análisis petrográficos para explorar la disponibilidad y el uso de materias primas en el sitio del pueblo de Kitkahahki (14RP1). Documentos históricos revelan grandes presiones y conflictos regionales en el área del pueblo de Kitkahahki durante su ocupación a finales del siglo XVIII y principios del XIX, procesos que pudieron haber alterado o restringido el movimiento de las mujeres fuera de los límites del pueblo. La cerámica pawnee de la era de contacto del pueblo de Kitkahahki exhibe texturas de pasta atípicas, inclusiones atípicas o ambas. Al menos una cerámica utilizó materiales atípicos disponibles en inmediaciones del pueblo, lo que sugiere que la colección de materia prima de la cerámica fue al menos ocasionalmente ajustada para reducir el riesgo. El análisis petrográfico contribuye a nuestra comprensión de las comunidades indígenas en los contextos coloniales, particularmente con relación a preguntas sobre cambio tecnológico y uso del paisaje cuando ambos fueron negociados intensamente y de cambio rápido.

Palabras clave: Great Plains, Pawnee, cerámicas, petrografía, período colonial

$\mathrm{B}$ $y$ the nineteenth century, nearly 2,000 years of Native pottery making on the North American Great Plains was coming to an end. This process of technological decline and eventual end of production is known as "senescence" (Hollenback and Schiffer 2010). Senescence may be linked to use-that is, older technology may be replaced because it meets a

Margaret E. Beck (margaret-beck@ uiowa.edu, corresponding author) — Department of Anthropology, University of Iowa, Iowa City, IA, USA

Richard L. Josephs $\square$ Department of Anthropology, University of North Dakota, Grand Forks, ND, USA

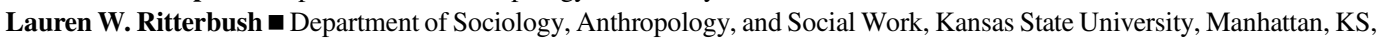
USA

Donna C. Roper $\mathbf{~ K a n s a s ~ S t a t e ~ U n i v e r s i t y , ~ M a n h a t t a n , ~ K S , ~ U S A ~}$

$\dagger$ This author died before publication of this article.

American Antiquity 87(2), 2022, pp. 248-266

Copyright (C) The Author(s), 2021. Published by Cambridge University Press on behalf of the Society for American Archaeology. This is an Open Access article, distributed under the terms of the Creative Commons Attribution licence (https://creativecommons.org/licenses/by/4.0/), which permits unrestricted re-use, distribution, and reproduction in any medium, provided the original work is properly cited.

doi:10.1017/aaq.2021.119 
need that no longer exists or because the need is better met by an alternative. Senescence may also be linked to production-namely, lack of raw materials, loss of producers' labor or the producers themselves, or loss of necessary knowledge (Hollenback and Schiffer 2010). Around the world, ceramic senescence often involves multiple factors, including changes in domestic utilitarian activities; accessibility of ceramic vessels; accessibility of alternatives; and the social, ideological, and political implications of a particular technology (e.g., Annis 1985; Beck 2009; Deal 1998; Sargent and Friedel 1986). Ceramic change and senescence was widespread in Native North America after European colonization due to a combination of these factors.

Here, we consider the last decades of ceramic manufacture among the Pawnee in the Central Great Plains, using petrographic analysis to explore raw material availability and use at the Kitkahahki Town site (14RP1). Raw material choices are often constrained by social and political factors (Neupert 1999), as has been documented for other Indigenous technologies in North American colonial settings (e.g., Brown 2018; Liebmann 2017). Historical documents reveal tremendous regional pressures and conflicts in the Kitkahahki Town area during its occupation in the late eighteenth and early nineteenth centuries-processes that could have altered or restricted the movement of women outside village boundaries. One or more potters here used a broader range of materials than earlier Indigenous potters in north-central Kansas, including materials unused since the Plains Woodland period nearly seven centuries earlier. These nontraditional materials may have been chosen because they were available immediately to the southeast of the village. We address raw material access as one factor interfering with ceramic production in the turbulent colonial period, at a time when ceramic senescence was already underway.

\section{Background}

The Pawnee historically spoke a Northern Caddoan language and occupied villages west of the Missouri River, first along the Loup and Platte River valleys in Nebraska and then expanding into the Republican River valley in southern Nebraska and northern Kansas (Figure 1; Parks and Wedel 1985). The Pawnee tribe is organized into four main bands-the Chawi (Grand), Kitkahahki (Republican), Pitahawirata (Tappage), and Skiri or Skidi (Loup) — and each band had multiple villages in Pawnee territory until AD 1859 (Echo-Hawk 1992; Roper 2006a; Wedel 1936; Weltfish 1971). Archaeological data suggest that ancestral Pawnee occupied the Loup and Platte River valleys by $\mathrm{AD}$ 1500, and Marquette's 1673 map also documents Pawnee in this region (Hyde 1974; O'Shea 1989; Wedel 1936, 1986). By 1777, the Kitkahahki band split from the Chawi and moved to the Republican River valley, establishing the southernmost known Pawnee villages (Hyde 1974:127; Kessler et al. 2021). In 1859, the four bands coalesced within a reservation along the Loup River, in part to reduce conflict with Euramerican settlers and to gain federal protection against Lakota Sioux groups. In 1876, after continuing encroachment from settler colonists and violent encounters with the Lakota, the Pawnee exchanged the Loup River reserve for a reservation in Indian Territory, now Oklahoma (Wedel 1936, 1986; Weltfish 1971).

Written documents offer only brief glimpses of the Pawnee until the Louisiana Purchase in 1803, when their territory came under the control of the United States. They interacted with French fur traders and missionaries in the eighteenth century, and by the start of the nineteenth century, they also were traveling southwest to trade with Spanish colonies (Hyde 1974). In 1804, Lewis and Clark collected information that identified Pawnee bands along the Loup and Platte Rivers. The earliest written description of a Pawnee village in any detail is by Lt. Zebulon Pike, who visited the Hill site (25WT1) along the Republican River in 1806 (Wedel 1936).

Weltfish (1971) depicts Pawnee life about 1867, based on her 1928-1936 ethnographic fieldwork with Pawnee elders in Oklahoma and additional historical research. Within these midnineteenth-century Pawnee villages, extended matrilineal families lived in substantial earthlodges (or mud lodges, as the Pawnee called them) with as many as 50 persons occupying each lodge. They farmed corn, beans, and 


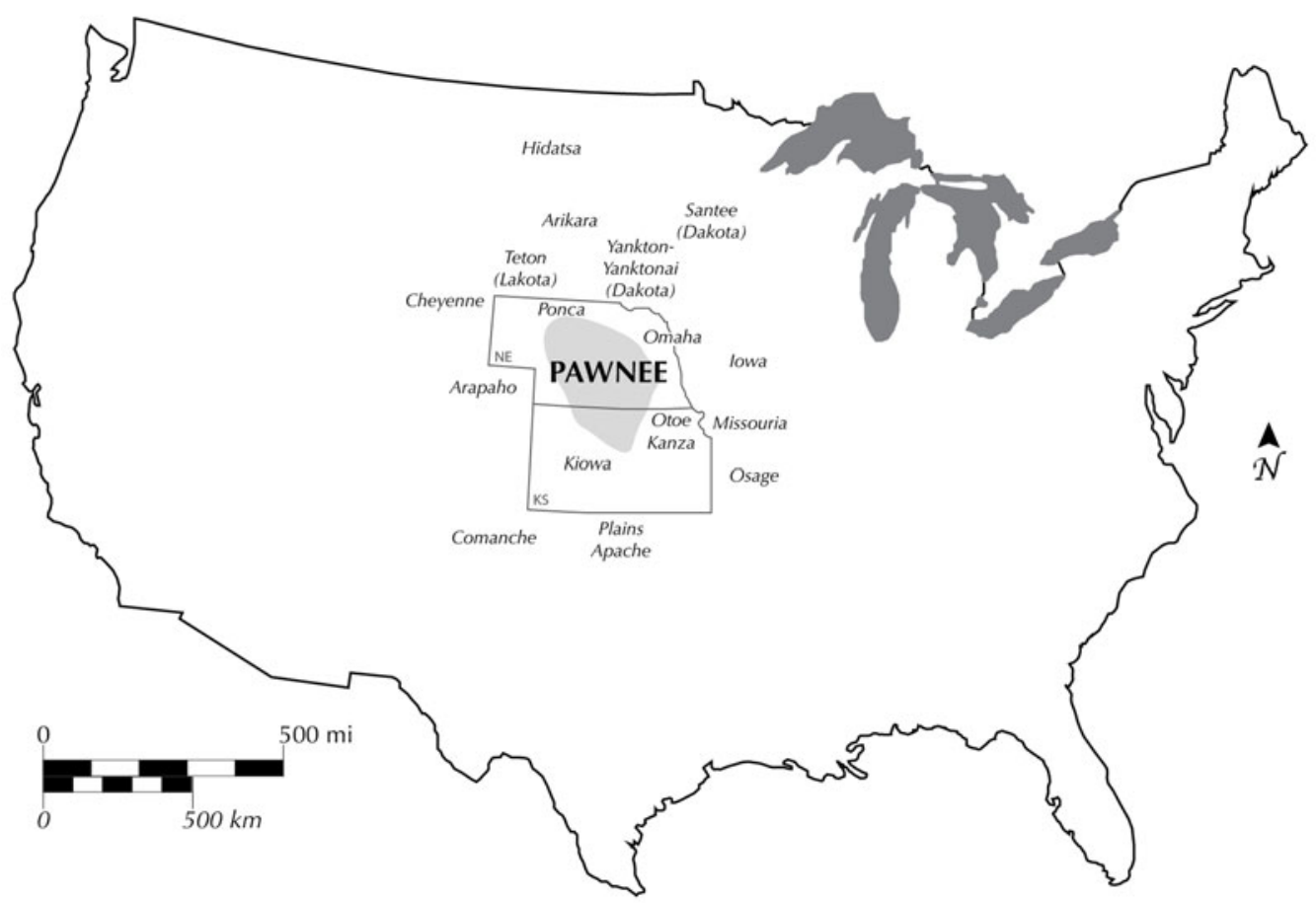

Figure 1. The Pawnee and their Indigenous neighbors in the early nineteenth century (based on DeMallie 2001).

squash, but they were also seasonally mobile, spending more than half the year away from villages during the summer and winter bison hunts. Weltfish's (1971) narrative is the most informative on Pawnee domestic life and subsistence by far, also drawing on the letters of Presbyterian missionary John Dunbar from his Pawnee mission in the 1830s and 1840s. Dunbar documents the 18341835 Chawi winter hunt in detail (see Roper 1991).

Pawnee economy and demography changed substantially during the European and American contact and colonial periods. Intruders presented a variety of threats, constraints, and opportunities to the region, reintroducing horses to North America and dramatically increasing demand for certain resources. By 1750, the Pawnee were fully equestrian, and the dogs that previously carried equipment and supplies during seasonal hunts were largely replaced by horses (Bozell 1988). By the early 1800 s, there were thousands of horses associated with every Pawnee village (Lowie 1982), and Pawnee bands traded thousands of bison hides to Europeans and Americans. In 1813, for example, the Chawi and Skiri bands traded roughly 2,000 robes in what seemed to be an average year (O'Shea 1989:67).

Europeans also introduced new infectious epidemic diseases to Indigenous communities throughout the Great Plains (Sundstrom 1997; Trimble 1989; Vehik 1989:Table 11). The abandonment of several ancestral Pawnee villages around AD 1750 suggests that measles and smallpox epidemics in AD 1734-1735 and AD 17501752 led to significant population loss (Johnson 1998; Trimble 1989). Later epidemics include the AD 1775-1782 smallpox pandemic, which affected the Northern and Central Plains in AD 1781-1782 (Fenn 2001; Hollenback 2012, 2017), and the AD 1832 smallpox epidemic, which may have reduced the Pawnee population by half (Hyde 1974). In Echo-Hawk's (2018) stories, he suggests that some residents of the Republican River valley had moved away from disease outbreaks in the larger Pawnee villages to the north.

\section{Ceramic Senescence in the Central Plains}

By the 1830s, the Pawnee ceramic traditionnever documented in writing by anyone who 
had seen the Pawnee make or use pottery-had come to an end (Beck 2020; Grange 1968). Pawnee women focused their artistic expression and skills on other media such as hidework, quillwork, and beadwork (Dubin 2003). Early scholars suggested that Plains peoples, including the Pawnee, "lost interest in the craft" of ceramic manufacture once they were able to obtain metal vessels and adopted the use of horses (Lowie 1982:60; see also Grange 1968; Strong 1935; Wedel 1936). It is now clear that instead of simply eschewing Indigenous material culture, Native groups in the Plains (e.g., Griffitts 2013; Rogers 1990; Scheiber and Finley 2010; Sundstrom 2002), as elsewhere in Native North America (e.g., Ferris 2009; Graesch et al. 2010; Law Pezzarossi 2014; Martelle 2004; Wagner 2010), selectively incorporated new objects and technologies that fit their functional, social, and ritual needs.

In the Northern Great Plains, Arikara and Hidatsa households continued to make ceramic vessels into the mid-nineteenth century, cooking with them for several generations even after acquiring metal kettles. The primary factors in Hidatsa and Arikara ceramic senescence are not use related but production related, including the epidemic-related deaths of many skilled potters, the resulting loss of instruction and knowledge, and the increased workload of survivors (Hollenback 2012, 2015, 2017; Krause 1972; Krause and Hollenback 2016). To the south in the Central Great Plains, epidemic disease and intensive hide working for European trade similarly disrupted Pawnee ceramic production (Beck 2020).

Cooking pots are in part an early "casualty of larger Pawnee economic decisions" that reallocated women's labor (Beck 2020:220-221). After roughly AD 1750, the Pawnee cooked their soups and other meals in metal rather than ceramic vessels. The few ceramic vessels made in the following decades seem only to have been used for "water storage and transport, paint storage, and ritual use" (Beck 2020:16). As people increasingly relied on metal tools for daily functions, traditional Pawnee objects of stone and ceramic apparently took on greater symbolic importance (Beck 2020; Hudson 1993).

\section{Raw Material Access in the Contact Period}

One factor not previously considered for Pawnee ceramics is raw material choice in a colonial setting marked by population shifts (both opportunistic and forced) and violence. As the Central Great Plains became more densely occupied (see Figure 1), conflicts over territories and resources increased. Drawing on earlier work (Irving 1956; John 1981; White 1978), Mark van de Logt summarized the increasingly threatened position of the Pawnee over time:

Between 1600 and 1850 there were four American Indian migrations to the Plains that challenged Pawnee power: the Athabascans (Apache and Navajo) arrived in the early 1600s; the Dhegihan Siouan tribes (Osage, Omaha, Ponca, Kaw, Otoe, Missouria, and Iowa) arrived in the late 1600s; the nomadic tribes (Lakota and Dakota Sioux, Cheyenne, Arapaho, Comanche, and Kiowa) arrived in the 1700s; and, finally, in the late 1820 s and early 1830 s, a fourth immigrant wave consisting of removed eastern tribes (such as Delaware, Potawatomi, and Kickapoo) entered the Plains. In short, by the late 1830 s, dozens of enemies surrounded the Pawnee. Author Washington Irving, who visited the Plains in 1832, observed that the Pawnee were "like the sons of Ishmael, their hand is against everyone and everyone's hand is against them" [van de Logt 2016:33].

People throughout the Great Plains raided other Indigenous groups in the precolumbian period (Habicht-Mauche 2008; Kehoe 2013), but raids apparently increased in frequency and devastation alongside the use of horses, the demand from both European and Native groups for captured people and livestock, and the need to replace or add women as wives or "drudge labor" (Kehoe 2013:39). By 1670, Apache groups to the southwest of the Pawnee acquired enough horses and metal weapons from the Spanish to pose a threat as raiders. When other Plains groups obtained horses and metal weapons (which happened for the Pawnee by 1719), they too began attacking and raiding their enemies (Hyde 1974). 
Ewers (1997:195) argues that "throughout most of the historic period of intertribal warfare on the Great Plains ... Indian women [as "valuable pawns in intertribal trade"] had more reason to fear being taken captive than being killed." Both captivity and death were distinct possibilities. Horses and people (women and children in particular) were in high demand, with people adopted into households to replace lost family members, added to the communities of their captors as extra labor, or sold at trade fairs (Brooks 2002; Ewers 1997; Lowie 1982). Captive women are a persistent theme in Traditions of the Skidi Pawnee (Dorsey and Murie 1904). Set in the time when the Skidi lived along the Platte River (prior to 1859), these traditions depict Skidi people raiding other tribes for scalps, slaves, and ponies and being raided themselves in turn.

In the 1920s, older members of the Pawnee Nation described nineteenth-century attacks on the outskirts of Pawnee villages along the Loup River. As retold by Gene Weltfish,

The Sioux made a particular point of attacking and scalping [Pawnee women] as they were going into the fields or coming home. This was presumably to exert sufficient pressure to chase the Pawnees from their territory and induce them to abandon it entirely. The mortality among the women from this cause was heavy. In 1861 in one such attack eighteen Skidi women were killed [Weltfish 1971:125].

This pattern is also documented in the early nineteenth century (Hyde 1974). As a result, women went to work in the agricultural fields in groups, with men stationed around the fields on some occasions (Hyde 1974; Lowie 1982; Weltfish 1971). Attacks could disrupt farming activities enough to cause food shortages and uncertainty (Jensen 2010; cf. van der Logt 2016:35), a problem faced by other Indigenous people in North America (Melton 2018). They also may have constrained other activities by women outside the village, such as ceramic raw material collection.

\section{Cultures and Ceramics in the Study Area}

Our work investigates clay and temper use at Kitkahahki Town, also known as the Kansas
Monument site (14RP1), in north-central Kansas (Figure 2). This site is a fortified Kitkahahki village along the Republican River near the mouth of White Rock Creek (Adair and Hofman 2021; Kessler et al. 2021; Roper 2006a). The village's primary occupation dates to approximately $\mathrm{AD}$ 1777-1802, with probable brief reoccupation in the following decades until 1831 (Kessler et al. 2021). Other known Kitkahahki villages along the Republican include the Hill site (25WT1) upstream from Kitkahahki Town-which was visited by Zebulon Pike in 1806-and the small, short-lived Bogan site (14GE1) downstream (Roper 2006a).

Using chronological and historical evidence, Kessler and colleagues (2021:484-485) argue that "groups of Kitkhahki splintered from the main Pawnee settlements in the Loup to establish and reoccupy villages in the Republican valley" during the period AD 1777-1831. This period is one of significant recorded conflict. In the last three decades of the eighteenth century, the Omaha and Ponca attacked Kitkahahki settlements; in the first decade of the nineteenth, the Kitkahahki were at war with the Skidi Pawnee as well as the Comanche (Hyde 1974). Attacks by the Kanza led the Kitkahahki to temporarily and then permanently abandon the Republican River villages (Roper 2006a). These communities at the southern extreme of Pawnee residential territory may have been particularly vulnerable to raiding, lacking the force in numbers of the villages along the Platte and Loup Rivers.

To consider how regional conflict may have changed Pawnee pottery at Kitkahahki Town, we need to first demonstrate that it changed. The ideal approach is a comparison of Pawnee or ancestral Pawnee raw material selection in the study area over time. Unfortunately, there are no fifteenth-, sixteenth-, or seventeenthcentury ancestral Pawnee sites or ceramic samples known in the study area. Kitkahahki Town is isolated relative to other Pawnee and ancestral Pawnee villages. It is located in a region with an apparent gap in residence in the more than three centuries prior to AD 1750. Like central Kansas, the study area in north-central Kansas may have seen only "transitory land use" over this period (Roper 2015:34). Ancestral Pawnee Lower Loup phase (AD 1500-1750) villages were 


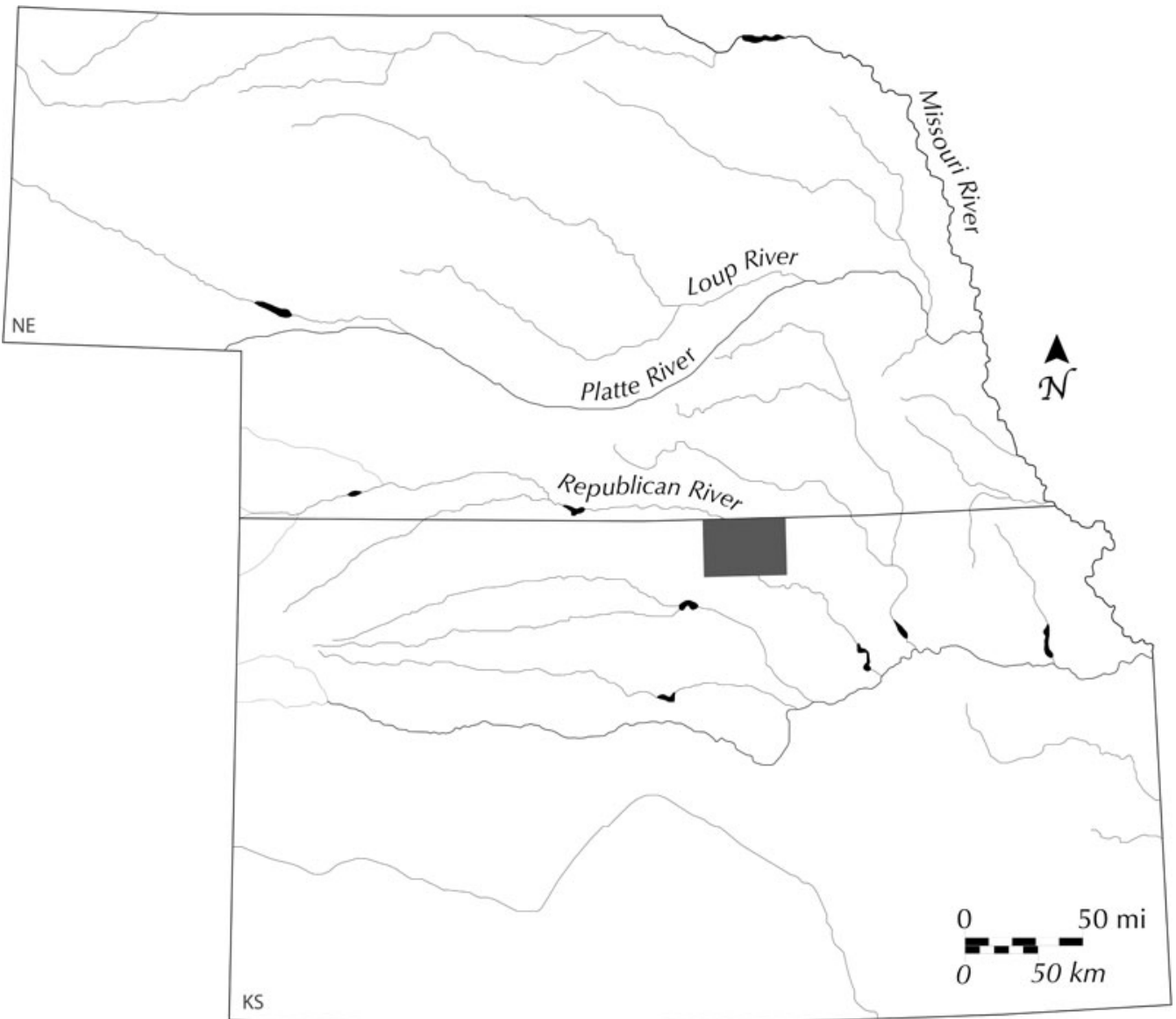

Figure 2. The study area (in gray) in relation to Kansas and Nebraska state boundaries.

located to the north, concentrated entirely along the Loup and Platte Rivers (Grange 1968; O'Shea 1989; Parks and Wedel 1985).

In his comprehensive study of Lower Loup and Pawnee ceramics from 41 sites or components, Grange (1968) does not observe changes in ceramic bodies over time. He writes that "most of the Pawnee and Lower Loup pottery is made of a fine to medium textured flaky paste sparsely tempered with crushed granite or sand. Other tempering materials include calcite, crushed limestone, and mica" (Grange 1968:44). He notes some "minor" variation in ceramic bodies, with denser temper at one site and "a tendency toward slightly coarser tempering particles" in some rim forms (Grange 1968:45). Overall, he argues that "none of these differences in paste are as significant in the definition of chronologically sensitive pottery types as are the characteristics of form and decoration (Grange 1968:45). Wedel (1936) states that both ancestral Pawnee and later Pawnee pottery was usually tempered with "fine" or "very fine sand, sparingly used" (Wedel 1936:66, 69).

The Central Plains tradition (AD 1100-1350), which is represented in north-central Kansas, is chronologically the next archaeological culture implicated in Pawnee ancestry (Roper 2006b; Roper et al. 2010). It is considered to be "ancestral, if not in a direct linear sense" to the Pawnee and "part of the complex cultural foundation" for later Northern Caddoan groups, including the Pawnee, Arikara, and Wichita (Ritterbush 2021:51). People represented by the Central Plains tradition occupied individual farmsteads or small farming hamlets scattered across the Central Plains, including in north-central Kansas 
and adjacent areas (Ritterbush 2021; Roper 2006b).

The closest investigated Central Plains tradition sites to Kitkahahki Town include the Phil (14JW48) and Windmill Creek (14JW49) sites in the Lovewell locality, approximately $19 \mathrm{~km}$ due west of Kitkahahki Town on White Rock Creek. Nearly all of the ceramics at the Phil and Windmill Creek sites are sand tempered, although no petrographic data are available (Ritterbush 2011; Ritterbush and Kobiskie 2007). The closest Central Plains tradition site for which petrographic data are available is Mugler (14CY1-A), along the Republican River approximately $86 \mathrm{~km}$ to the southeast (Beck 2001; Roper et al. 2010). At Mugler, weakly bimodal or bimodal particle size distributions reveal intentionally added temper of subrounded to rounded coarse and very coarse sand of roughly $10 \%-15 \%$ of the ceramic body volume. Other temper types represented are grog and shell. Mugler was one of seven Central Plains tradition sites included in a regional petrographic study (Roper et al. 2010). Naturally occurring inclusions in the paste (present in both sandtempered and shell-tempered ceramics) reflect the local geological setting of each site and include fragments of Cretaceous or Permian sedimentary rock (sandstone, shale, limestone, or chert) as well as igneous or metamorphic rock fragments from glacial till. Subrounded to rounded particle shape suggests the consistent use of sand rather than crushed rock as temper.

Alluvial clay use may have been common across the Northern and Central Plains after AD 1000 , based on redoximorphic nodule frequency in ceramics from Central Plains tradition (Beck 2001; Roper et al. 2010), Initial Variant of the Middle Missouri tradition (Beck and Hannus 2020), and post-AD 1600 Hidatsa ceramics along the Knife River in North Dakota (Hollenback 2017). Pastes with 10\%-20\% silt-size grains are also common, as determined by petrographic point counting (Beck 2001; Beck and Hannus 2020; Stoltman and Tiffany 2016), although occasional examples are siltier with $30 \%-40 \%$ silt and very fine sand (Beck 2001).

In summary, groups directly or indirectly ancestral to the post-AD 1750 Kitkahahki-at least those after AD 1100-made ceramics with a fine or medium texture and added sparse to moderate amounts of temper. For deviation from this pattern, we must look at preceding Woodland or transitional Woodland and Central Plains tradition ceramics. During the Keith phase of the Plains Woodland period (AD 400-1100), potters in north-central Kansas often used crushed rock as temper, up to $30 \%$ of the ceramic body volume. Crushed rock was identified as subangular to angular particles of crystalline calcite, limestone, or polymineralic grains with quartz and feldspar that range from very coarse sand to gravel in size (Hoard et al. 2017). Coarse angular particles of limestone or bone were also used as temper in central Kansas, appearing in thicker-walled vessels with only slightly restricted necks that predate classic Central Plains tradition globular jars (Roper 2015).

In the absence of an ancestral Pawnee site in the immediate area of Kitkahahki Town, we have included the closest known habitation site for which petrographic data are available as a geographic control. This is the White Rock site (14JW1), occupied in the late 1200s by migrant Oneota bison hunters of the White Rock phase. The Oneota archaeological tradition, widespread in the Midwest and Eastern Plains, is ancestral to a number of later Siouan-language-speaking groups. The White Rock site is on the north side of White Rock Creek (now Lovewell Reservoir), approximately $19 \mathrm{~km}$ directly west of the Kitkahahki Town site. It represents a village or repeatedly used central base camp of bison hunters who also gardened in the valley (Logan 1995, 1998, 2010a; Ritterbush 2002, 2006; Ritterbush and Logan 2000). White Rock phase ceramics are typically sand tempered, and they occasionally include crushed bone. Finely crushed freshwater mussel shell is present in some sherds, but it is often sparse, fine, and partially or completely dissolved or leached (Ritterbush 2001, 2006; Rusco 1960). Although potters at the White Rock site belonged to a different cultural tradition, the ceramics here provide useful comparative data for this geographic and geological setting.

\section{Geology and Raw Materials in the Study Area}

The Kitkahahki Town and White Rock sites are within the Smoky Hills physiographic region 


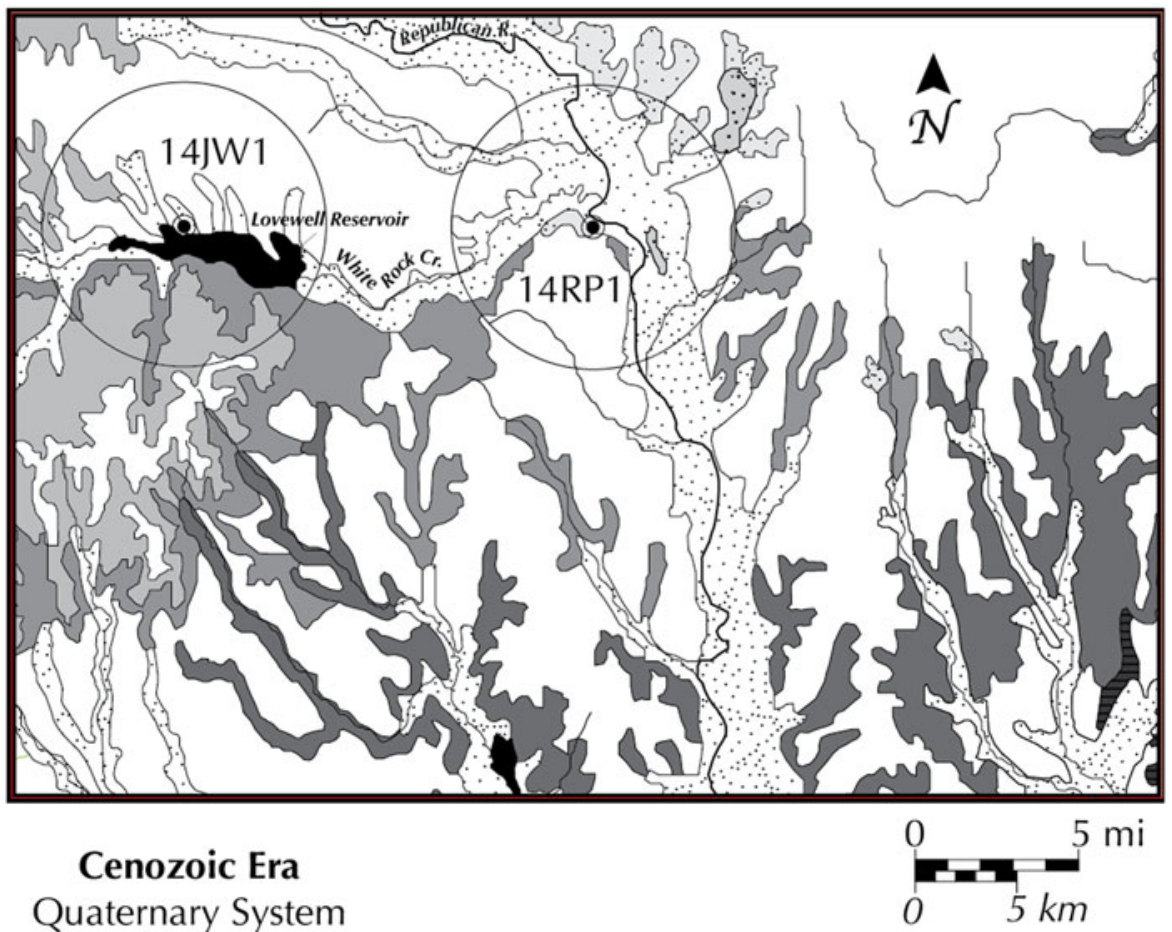

$\therefore$ Alluvium (late Pleistocene and Holocene)

a. Dune sand

\title{
Loess
}

:: Alluvium (early Pleistocene)

\author{
Mesozoic Era \\ Cretaceous System \\ Niobrara Chalk \\ Carlile Shale \\ Greenhorn Limestone \\ E Dakota Formation
}

Figure 3. Surface geology and site locations. Surface geology is based on geologic maps for Jewell County and Republican County, Kansas (published online at http://www.kgs.ku.edu/General/Geology/index.html).

(Wilson 1984). The uplands are formed from Cretaceous sandstone, limestone, and shale, with underlying Lower Cretaceous series rocks to the east and overlying Upper Cretaceous series lithologies to the west (Figure 3; O'Connor 2005). Quaternary alluvium is mapped along the floodplains. The Central Plains tradition site of Mugler along the Republican River is located within a similar sedimentary landscape in the Smoky Hills but with older exposed deposits. These include Lower Cretaceous Dakota formation sandstone and Permian-age shales and limestones (Roper et al. 2010).

Potters at Kitkahahki Town and at other sites in north-central Kansas likely used a combination of raw materials that were collected from 
local outcrops and from alluvium with extralocal rock and mineral debris, including Quaternary glaciogenic sediments (see Figure 3). We focus here on materials available within $7 \mathrm{~km}$ of Kitkahahki Town and White Rock. Arnold's (1988:55) compilation of global ethnographic data indicates that potters collect clay at a maximum distance of $7 \mathrm{~km}$ from the place of manufacture and temper at a maximum distance of 6 and $9 \mathrm{~km}$. Within a $7 \mathrm{~km}$ radius around the Kitkahahki Town site, raw materials may originate from alluvium, loess, or the Carlile Shale; the underlying Greenhorn Limestone, potentially exposed in bluffs along the Republican River, may also be a source (see O'Connor 2005). The available raw materials are similar to the west at the White Rock site, but they include the addition of Niobrara Chalk and more extensive exposures of Carlile Shale.

\section{Sample and Methods}

We collected new petrographic data from 30 body sherds from the Kitkahahki Town site and 11 from White Rock. The Kitkahahki Town ceramics were recovered during the 1965-1968 excavations by the Kansas Historical Society: five each from Houses 3, 5, and 6; four from House 24; three each from Houses 4, 7, and 25; and two from exterior excavation units (Unit 33, within a possible midden area, and Unit 595). The White Rock site sherds were collected from a large trash-filled pit excavated in 1993 and another pit feature excavated in 2009 (Logan 2010b; Logan and Banks 1994).

Thin sections were prepared by National Petrographic Service Inc. in Houston, Texas. A Nikon Optiphot Pol microscope was used to identify minerals, rock fragments, and other inclusions in the body, or "the bulk composition of a ceramic vessel, including clays, larger natural mineral inclusions ... and temper" (Stoltman 1991:109-110; see also Josephs 2005a, 2005b, 2011; Roper et al. 2010). We also recorded particle size distribution, size range, particle shape, and particle alignment (Quinn 2013), along with the presence of naturally occurring nodules in the clay matrix that are redoximorphic features resulting from the redistribution of iron and manganese during saturation and reduction in soils (Josephs 2005a, 2005b, 2011; Roper et al. 2010; Stoops 2003). These appear in periodically waterlogged sediments and can be incorporated into finished ceramic vessels, even when potters vigorously mix clay (see discussion in Beck 2001; Beck and Neupert 2009).

"Paste," as defined in this study, includes the clay matrix (micromass), silt, fine sand, and medium sand, all presumed to be naturally occurring inclusions. This decision is based on strongly bimodal particle size distributions (Quinn 2013) in some White Rock samples, in which intentionally added temper particles are usually coarse sand-sized or larger. Medium sand also appears in White Rock samples alongside bone and shell temper, although it is possible that the medium sand was intentionally added. This definition of "paste" may be too conservative for the Kitkahahki Town samples, which almost always have unimodal particle size distributions, suggesting use of self-tempered clays with no intentionally added temper (Quinn 2013).

Paste texture categories describe the particle size and density in the paste or "the aggregate of natural materials . . . to which temper was later added" (Stoltman 1991:109-110). Particle size definitions here are like those used in previous studies (Beck and Hannus 2020; Stoltman 1989, 1991): matrix (no particle could be visually distinguished), silt (visible particle smaller than $0.0625 \mathrm{~mm}$ on a side), fine sand $(0.0625$ $0.2500 \mathrm{~mm})$, medium sand $(0.25-0.50 \mathrm{~mm})$, coarse sand $(0.5-1.0 \mathrm{~mm})$, very coarse sand (1.0 $2.0 \mathrm{~mm}$ ), and gravel (larger than $2.0 \mathrm{~mm}$ ). Particle density, or percent area of the ceramic paste, was visually estimated with a chart (Quinn 2013: Figure 4.9; see also Bullock et al. 1985) and through comparisons to point-counted sherds from a previous study (Beck and Hannus 2020). Identified paste texture categories are low silt (less than 5\%) with little to no fine-medium sand, $10 \%-20 \%$ silt with little to no fine-medium sand, and 20\%-30\% silt and fine-medium sand combined.

\section{Results}

We defined six body groups using presenceabsence data of sedimentary, igneous, and metamorphic rock types and their constituent minerals (Table 1; Figure 4). Group definitions do not 
Table 1. Defined Body Groups and Identified Inclusions by Sample.

\begin{tabular}{|c|c|c|c|c|c|c|c|c|c|c|c|c|c|c|c|c|}
\hline Group & $\#$ & $\mathrm{Qz}$ & Kfs & $\mathrm{Pl}$ & $\mathrm{Bt}$ & Ms & Grt & Sst & Sltst & Sh & $\mathrm{Cal}$ & Ls & Foss & Cht & Sch & Bone \\
\hline 1 & 216 & $\mathrm{x}$ & $\mathrm{x}$ & $\mathrm{x}$ & & & & & & & & & & & & \\
\hline 1 & 217 & $\mathrm{x}$ & $\mathrm{x}$ & $\mathrm{x}$ & & & & & & & & & & & & \\
\hline 2 & 214 & $\mathrm{x}$ & $\mathrm{x}$ & $\mathrm{x}$ & & & & $\mathrm{x}$ & & & & & & & & \\
\hline 2 & 219 & $\mathrm{x}$ & $\mathrm{x}$ & $\mathrm{x}$ & & & & $\mathrm{x}$ & & & & & & & & \\
\hline 2 & 222 & $\mathrm{x}$ & $\mathrm{x}$ & $\mathrm{x}$ & & & & $\mathrm{x}$ & & & & & & & & \\
\hline 3 & 213 & $\mathrm{x}$ & $\mathrm{x}$ & $\mathrm{x}$ & $\mathrm{x}$ & $\mathrm{x}$ & & $\mathrm{x}$ & & & & & & $\mathrm{x}$ & & \\
\hline 3 & 211 & $\mathrm{x}$ & $\mathrm{x}$ & $\mathrm{x}$ & $\mathrm{x}$ & $\mathrm{x}$ & & $\mathrm{x}$ & & & & & & $\mathrm{x}$ & & \\
\hline 3 & 215 & $\mathrm{x}$ & $\mathrm{x}$ & $\mathrm{x}$ & $\mathrm{x}$ & $\mathrm{x}$ & & $\mathrm{x}$ & & & & & & & & \\
\hline 3 & 212 & $\mathrm{x}$ & $\mathrm{x}$ & $\mathrm{x}$ & $\mathrm{x}$ & $\mathrm{x}$ & & $\mathrm{x}$ & $\mathrm{x}$ & & & & & $\mathrm{x}$ & & $\mathrm{x}$ \\
\hline 3 & 218 & $\mathrm{x}$ & $\mathrm{x}$ & $\mathrm{x}$ & $\mathrm{x}$ & $\mathrm{x}$ & $\mathrm{x}$ & $\mathrm{x}$ & $\mathrm{x}$ & & & & & $\mathrm{x}$ & & \\
\hline 3 & 223 & $\mathrm{x}$ & $\mathrm{x}$ & $\mathrm{x}$ & $\mathrm{x}$ & $\mathrm{x}$ & $\mathrm{x}$ & $\mathrm{x}$ & & & & & & & & \\
\hline 3 & 224 & $\mathrm{x}$ & $\mathrm{x}$ & $\mathrm{x}$ & $\mathrm{x}$ & $\mathrm{x}$ & $\mathrm{x}$ & $\mathrm{x}$ & & & & & & $\mathrm{x}$ & & \\
\hline 3 & 225 & $\mathrm{x}$ & $\mathrm{x}$ & $\mathrm{x}$ & $\mathrm{x}$ & $\mathrm{x}$ & $\mathrm{x}$ & $\mathrm{x}$ & $\mathrm{x}$ & & & & & $\mathrm{x}$ & & \\
\hline 3 & $226^{\mathrm{a}}$ & $\mathrm{x}$ & $\mathrm{x}$ & $\mathrm{x}$ & $\mathrm{x}$ & $\mathrm{x}$ & & $\mathrm{x}$ & $\mathrm{x}$ & & & & & $\mathrm{x}$ & & $\mathrm{x}$ \\
\hline 3 & 228 & $\mathrm{x}$ & $\mathrm{x}$ & $\mathrm{x}$ & $\mathrm{x}$ & $\mathrm{x}$ & $\mathrm{x}$ & $\mathrm{x}$ & & & & & & $\mathrm{x}$ & & \\
\hline 3 & 231 & $\mathrm{x}$ & $\mathrm{x}$ & $\mathrm{x}$ & $\mathrm{x}$ & $\mathrm{x}$ & & $\mathrm{x}$ & $\mathrm{x}$ & & & & & $\mathrm{x}$ & & \\
\hline 3 & 232 & $\mathrm{x}$ & $\mathrm{x}$ & $\mathrm{x}$ & $\mathrm{x}$ & $\mathrm{x}$ & $\mathrm{x}$ & $\mathrm{x}$ & & & & & & $\mathrm{x}$ & & \\
\hline 3 & 209 & $\mathrm{x}$ & $\mathrm{x}$ & $\mathrm{x}$ & $\mathrm{x}$ & $\mathrm{x}$ & $\mathrm{x}$ & $\mathrm{x}$ & & & & & & & & \\
\hline 4 & 208 & $\mathrm{x}$ & $\mathrm{x}$ & $\mathrm{x}$ & $\mathrm{x}$ & & & $\mathrm{x}$ & & & $\mathrm{x}$ & $\mathrm{x}$ & & & & $\mathrm{x}$ \\
\hline 4 & 221 & $\mathrm{x}$ & $\mathrm{x}$ & $\mathrm{x}$ & $\mathrm{x}$ & $\mathrm{x}$ & & $\mathrm{x}$ & & & $\mathrm{x}$ & & & & & \\
\hline 4 & 230 & $\mathrm{x}$ & $\mathrm{x}$ & $\mathrm{x}$ & $\mathrm{x}$ & $\mathrm{x}$ & & $\mathrm{x}$ & & & $\mathrm{x}$ & $\mathrm{x}$ & & & & \\
\hline 4 & 234 & $\mathrm{x}$ & $\mathrm{x}$ & $\mathrm{x}$ & $\mathrm{x}$ & $\mathrm{x}$ & & $\mathrm{x}$ & & & $\mathrm{x}$ & & & & & \\
\hline 4 & 235 & $\mathrm{x}$ & $\mathrm{x}$ & $\mathrm{x}$ & $\mathrm{x}$ & $\mathrm{x}$ & $\mathrm{x}$ & $\mathrm{x}$ & & & $\mathrm{x}$ & & & $\mathrm{x}$ & & \\
\hline 4 & 207 & $\mathrm{x}$ & $\mathrm{x}$ & $\mathrm{x}$ & $\mathrm{x}$ & & & $\mathrm{x}$ & & & $\mathrm{x}$ & $\mathrm{x}$ & & $\mathrm{x}$ & & \\
\hline 4 & 227 & $\mathrm{x}$ & $\mathrm{x}$ & $\mathrm{x}$ & $\mathrm{x}$ & $\mathrm{x}$ & & $\mathrm{x}$ & & & & $\mathrm{x}$ & & $\mathrm{x}$ & & $\mathrm{x}$ \\
\hline 5 & 229 & $\mathrm{x}$ & $\mathrm{x}$ & $\mathrm{x}$ & $\mathrm{x}$ & $\mathrm{x}$ & & $\mathrm{x}$ & & & $\mathrm{x}$ & $\mathrm{x}$ & $\mathrm{x}$ & $\mathrm{x}$ & & $\mathrm{x}$ \\
\hline 5 & 210 & $\mathrm{x}$ & $\mathrm{x}$ & $\mathrm{x}$ & $\mathrm{x}$ & $\mathrm{x}$ & & $\mathrm{x}$ & & & $\mathrm{x}$ & & $\mathrm{x}$ & $\mathrm{x}$ & & \\
\hline 5 & 220 & $\mathrm{x}$ & $\mathrm{x}$ & $\mathrm{x}$ & $\mathrm{x}$ & $\mathrm{x}$ & & $\mathrm{x}$ & & & $\mathrm{x}$ & $\mathrm{x}$ & $\mathrm{x}$ & $\mathrm{x}$ & & \\
\hline 5 & 233 & $\mathrm{x}$ & $\mathrm{x}$ & $\mathrm{x}$ & $\mathrm{x}$ & $\mathrm{x}$ & & $\mathrm{x}$ & & & $\mathrm{x}$ & & $\mathrm{x}$ & $\mathrm{x}$ & & \\
\hline 6 & 236 & & & & & & & & & & & & $\mathrm{x}$ & & & \\
\hline
\end{tabular}

White Rock site (14JW1): sample \# prefix LWR-

\begin{tabular}{|c|c|c|c|c|c|c|c|c|c|c|c|c|c|c|c|c|}
\hline Group & \# & $\mathrm{Qz}$ & Kfs & $\mathrm{Pl}$ & $\mathrm{Bt}$ & Ms & Grt & Sst & Sltst & Sh & Cal & Ls & Foss & Cht & Sch & Bone \\
\hline 1 & 007 & $\mathrm{x}$ & $\mathrm{x}$ & $\mathrm{x}$ & & & & & & & & & & & & \\
\hline 2 & 008 & $\mathrm{x}$ & $\mathrm{x}$ & $\mathrm{x}$ & & & & $\mathrm{x}$ & & & & & & & & \\
\hline 2 & 013 & $\mathrm{x}$ & $\mathrm{x}$ & $\mathrm{x}$ & & & & $\mathrm{x}$ & & & & & & & & \\
\hline 3 & 001 & $\mathrm{x}$ & $\mathrm{x}$ & $\mathrm{x}$ & $\mathrm{x}$ & $\mathrm{x}$ & & $\mathrm{x}$ & & & & & & & & \\
\hline 3 & 002 & $\mathrm{x}$ & $\mathrm{x}$ & $\mathrm{x}$ & $\mathrm{x}$ & $\mathrm{x}$ & $\mathrm{x}$ & $\mathrm{x}$ & & $\mathrm{x}$ & & & & & & \\
\hline 3 & 003 & $\mathrm{x}$ & $\mathrm{x}$ & $\mathrm{x}$ & $\mathrm{x}$ & $\mathrm{x}$ & & $\mathrm{x}$ & & $\mathrm{x}$ & & & & $\mathrm{x}$ & & \\
\hline 3 & 004 & $\mathrm{x}$ & $\mathrm{x}$ & $\mathrm{x}$ & $\mathrm{x}$ & $\mathrm{x}$ & & $\mathrm{x}$ & & & & & & & & \\
\hline 3 & 005 & $\mathrm{x}$ & $\mathrm{x}$ & $\mathrm{x}$ & $\mathrm{x}$ & & & $\mathrm{x}$ & & $\mathrm{x}$ & & & & & $\mathrm{x}$ & \\
\hline 3 & 006 & $\mathrm{x}$ & $\mathrm{x}$ & $\mathrm{x}$ & $\mathrm{x}$ & $\mathrm{x}$ & & $\mathrm{x}$ & & & & & & & & \\
\hline 3 & 009 & $\mathrm{x}$ & $\mathrm{x}$ & $\mathrm{x}$ & $\mathrm{x}$ & $\mathrm{x}$ & & $\mathrm{x}$ & & $\mathrm{x}$ & & & & & & $\mathrm{x}$ \\
\hline 3 & 014 & $\mathrm{x}$ & $\mathrm{x}$ & $\mathrm{x}$ & $\mathrm{x}$ & & & $\mathrm{x}$ & & & & & & & & \\
\hline
\end{tabular}

Notes: Inclusions are quartz (Qz), potassium feldspar (Kfs), plagioclase feldspar (Pl), biotite mica (Bt), muscovite mica (Ms), granite/gneiss (Grt), sandstone (Sst), siltstone (Sltst), shale (Sh), calcite (Cal), limestone (Ls), fossil shell (Foss), chert (Cht), schist (Sch), and bone. Body groups are 1 (Qz-Kfs-Pl), 2 (Group 1 inclusions + Sst), 3 (Group 2 inclusions + Bt-Ms; Grt, Sltst, Sh, Sch possible), 4 (Group 2 inclusions + Bt-Ms + Cal-Ls), 5 (Group 4 inclusions + Foss), and 6 (Foss).

${ }^{\mathrm{a}}$ Hornblende $(\mathrm{Hbl})$ also present. 

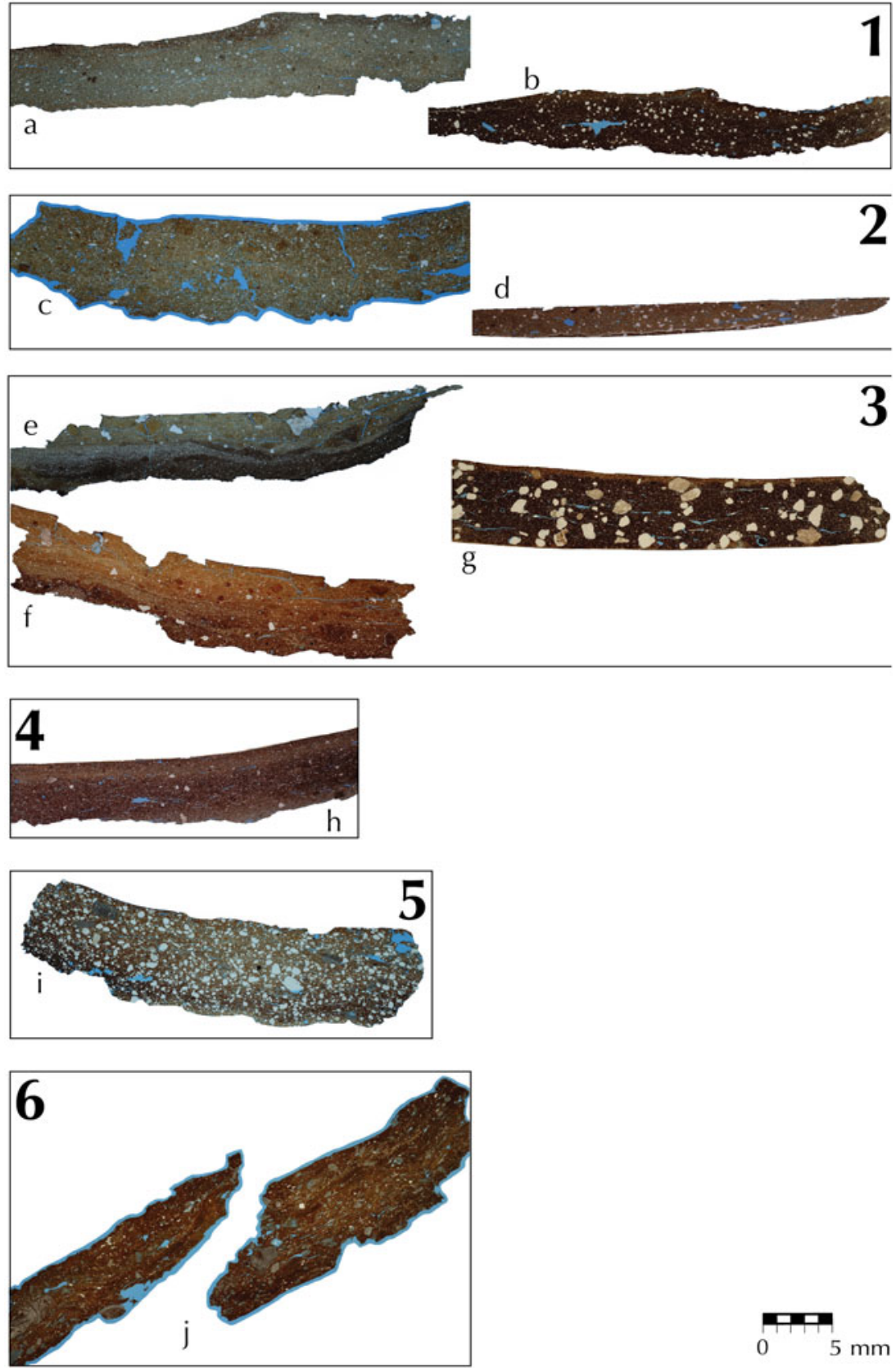

Figure 4. Examples of six defined body groups from (left) Kansas Monument and White Rock: (a) DCR-217, (b) LWR-007, (c) DCR-222, (d) LWR-013, (e) DCR-215, (f) DCR-211, (g) LWR-002, (h) DCR-235, (i) DCR-210, (j) DCR-236. (Color online)

consider organic materials such as bone or shell, although these are present (or originally present but subsequently leached away) in several sherds. All six body groups appear to reflect materials available within $7 \mathrm{~km}$ of each site, including alluvium with extralocal rock and mineral debris from glaciogenic sediments (e.g., granite/gneiss and micaceous schist) and 
nearby Upper Cretaceous sedimentary formations with shale, siltstone, sandstone, limestone, and chert. Identifiable rock fragments were at least medium sand in size, and all have subangular to subrounded particle shapes, suggesting that their origin is from sand rather than crushed rock (with the possible exception of softer sedimentary rock such as shale or limestone).

Group 1 samples include only quartz and feldspar, whereas Group 2 samples include quartz, feldspar, and sandstone fragments. They are distinguished by the absence of mica (biotite or muscovite or both; see Table 1). All samples in these two groups have subangular to subrounded particle shapes and unimodal or weakly bimodal particle size distributions, with grains up to coarse or very coarse sand in size (see Table 2). All have fine pastes with 10\%-20\% silt and redoximorphic features. Group 1 and 2 samples are interpreted as reflecting use of alluvial clays and sands composed of the minerals most resistant to weathering.

Group 3 samples are like those in Group 2 with quartz, feldspar, and sandstone, but they also include fragments of other sedimentary rocks (siltstone, shale, and chert). Granite/gneiss or schist fragments from glaciogenic sediments may also be present (see Table 1). All samples in Group 3 have grains up to coarse or very coarse sand or gravel in size (see Table 2). The Kitkahahki Town samples have unimodal particle size distributions. Some have fine pastes with $10 \%-20 \%$ silt or less and redoximorphic features, but most have sandy pastes with $20 \%-$ $30 \%$ silt and fine-medium sand and almost no visible redoximorphic features (see Table 3 ). The White Rock samples are usually strongly bimodal in particle size, indicating added temper, and all have fine pastes with 10\%-20\% silt and redoximorphic features (see Tables 2 and 3). The mineralogically diverse sands in Group 3 may be present in some cases because potters at Kitkahahki Town chose sandier, self-tempered clays to use alone or mix with other clays. In other cases, it is because potters at both Kitkahahki Town and White Rock added these sands to finer alluvial clays. Several Group 3 samples at Kitkahahki Town (e.g., DCR-215; Figure 4e) reveal incomplete mixing of sediments with different silt or sand percentages, a trait absent in all of the White Rock samples.
Group 3 is the most common body group at both Kitkahahki Town and White Rock (see Table 1). The mix of rock fragments in Group 3 is typical for the study area and for earlier Central Plains tradition ceramics in the region (Roper et al. 2010), although regional ceramics may have less mineralogical diversity (Groups 1-2; Beck 2001; Roper et al. 2010).

Only samples from Kitkahahki Town fall into Groups 4-6. Group 4 samples include crystalline calcite or gypsum or both, often accompanied by micritic limestone and fragments of other sedimentary rocks; they almost always lack granite/ gneiss (see Table 1). Group 5 samples are similar to Group 4, but with the addition of fossil shell. Sample (DCR-236) is alone in Group 6, with only silt and fossil shell inclusions. Some samples in Groups 4-6 have fine pastes with 10\%-20\% silt and redoximorphic features, but others have sandy pastes with $20 \%-30 \%$ silt and fine-medium sand and almost no visible redoximorphic features (see Table 3). This may reflect the use of both finer alluvial clays with added temper and sandier, self-tempered clays by Kitkahahki Town potters.

The fossil shell fragments in Groups 5 and 6 probably derive from fossil marine mollusks (Inoceramus and Ostrea), which are abundant in the Niobrara Chalk, Carlile Shale, and Greenhorn Limestone Formations (O'Connor 2005). We suggest the Carlile Shale Formation in particular as a major contributor of sedimentary rock fragments and fossil shell, because it crops out along the Republican River and White Rock Creek within $2 \mathrm{~km}$ of both the Kitkahahki Town and White Rock sites. Crystals of selenite-a variety of gypsum-are common in the Blue Hill Shale Member of the Carlile Shale, as are calcite crystals (Hattin 1962; O’Connor 2005).

\section{Discussion}

For interpretive purposes in our discussion, we reduce paste texture and body composition groups into "typical" and "atypical" categories (see Table 3), with "typical" conforming to regional raw material use patterns after $\mathrm{AD}$ 1100 and "atypical" deviating from these patterns. "Typical" paste texture represents a finetextured alluvial clay, with visible redoximorphic 
Table 2. Observations on Inclusions.

Kitkahahki Town (14RP1): sample \# prefix DCR-

\begin{tabular}{|c|c|c|c|c|c|c|}
\hline Group & \# & Size Distribution & Size Range & Shape & Alignment & Notes \\
\hline 1 & 216 & unimodal & VF-F, VC $(n=1)$ & sa-sr & none & dominated by very-fine-sand-sized, monomineralic grains \\
\hline 1 & 217 & unimodal & VF-M, C $(n=1), \operatorname{VC}(n=1)$ & sa-sr & none & \\
\hline 2 & 214 & unimodal & VF-VC & sa-sr & none & \\
\hline 2 & 219 & unimodal & VF-C & sa-sr & none & dense concentration of very-fine-sand-sized grains \\
\hline 2 & 222 & weakly bimodal & VF-C & sa-sr & none & \\
\hline 3 & 213 & unimodal & VF-VC & sa-sr & none & \\
\hline 3 & 211 & unimodal & VF-C & sa-sr & none & \\
\hline 3 & 215 & unimodal & VF-VC & sa-sr & none to moderate & $\begin{array}{l}0.50-1.25 \mathrm{~mm} \text { thick horizontal band of well sorted, very-fine-sand-sized grains in a } \\
\text { darker, mosaic-speckled, micromass; grains display a moderately expressed parallel } \\
\text { lineation, consistent with stress applied perpendicular to the long axis of the band }\end{array}$ \\
\hline 3 & 212 & unimodal & VF-VC & sa-sr & none & \\
\hline 3 & 218 & unimodal & VF-VC & sa-sr & none & \\
\hline 3 & 223 & unimodal & VF-VC & sa-sr & none & \\
\hline 3 & 224 & unimodal & VF-VC & sa-sr & none & \\
\hline 3 & 225 & unimodal & VF-VC & sa-sr & none & \\
\hline 3 & 226 & unimodal & VF-M, VC $(n=1)$ & sa-sr & moderate & contains oxidized bone fragment, roughly triangular in shape $(0.125 \mathrm{~mm}$ per side $)$ \\
\hline 3 & 228 & unimodal & VF-VC & sa-sr & none & \\
\hline 3 & 231 & unimodal & VF-C & sa-sr & none & $\begin{array}{l}\text { dominated by very-fine-sand-sized, monomineralic grains; numerous chert fragments in a } \\
\text { variety of sizes }\end{array}$ \\
\hline 3 & 232 & unimodal & VF-C & sa-sr & none & \\
\hline 3 & 209 & unimodal & $\mathrm{VF}-\mathrm{VC}, \mathrm{G}(n=1)$ & sa-sr & none & \\
\hline 4 & 208 & unimodal & VF-VC & sa-sr & none & \\
\hline 4 & 221 & unimodal & VF-M & sa-sr & none & \\
\hline 4 & 230 & unimodal & VF-C & sa-sr & none & dominated by very-fine-sand-sized, monomineralic grains \\
\hline 4 & 234 & unimodal & VF-C & sa-sr & none & $\begin{array}{l}\text { dominated by very-fine-sand-sized, monomineralic grains; one triangular inclusion } \\
(\sim 0.75 \mathrm{~mm} \text { per side }) \text { with random, acicular crystal intergrowths of gypsum }\end{array}$ \\
\hline 4 & 235 & unimodal & VF-C & sa-sr & none & dominated by very-fine-sand-sized, monomineralic grains \\
\hline 4 & 207 & unimodal & VF-C, G $(n=1)$ & sa-sr & none & $\begin{array}{l}\text { several fine- to medium-sand-sized calcite spherules, some present within large limestone } \\
\text { fragment }\end{array}$ \\
\hline 4 & 227 & unimodal & VF-M; VC $(n=2)$ & sa-sr & none & $\begin{array}{l}\text { includes one VC grog inclusion; radiating (fan-shaped) crystal growth of gypsum in some } \\
\text { planes }\end{array}$ \\
\hline 5 & 229 & unimodal & VF-C & sa-sr & none & $\begin{array}{l}\text { dominated by very-fine-sand-sized, monomineralic grains (larger grains, } \sim 5 \% \text { ); bone } \\
\text { fragments present }\end{array}$ \\
\hline 5 & 210 & unimodal & VF-VC & sa-sr & none & larger grains are rounded \\
\hline
\end{tabular}



220 unimodal
VF-VC
sa-sr none
233 unimodal
VF-C
sa-sr none
sa-sr none to moderate
linear concentration $(0.25 \mathrm{~mm}$ wide $\times 3.50 \mathrm{~mm}$ long $)$ of very-fine-sand-sized grains

6236 unimodal VF-G

White Rock site (14JW1): sample \# prefix LWR-

\begin{tabular}{|c|c|c|c|c|c|c|}
\hline Group & \# & Size Distribution & Size Range & Shape & Alignment & Notes \\
\hline 1 & 007 & weakly bimodal & Si-F; M, C $(n=1)$ & sa-sr & none & \\
\hline 2 & 008 & weakly bimodal & $\mathrm{Si}-\mathrm{M} ; \mathrm{C}(n=1)$ & sa-sr & poor & rectilinear voids from leached shell; one coarse sandstone fragment \\
\hline 2 & 013 & weakly bimodal & $\mathrm{Si}-\mathrm{VF} ; \mathrm{M}-\mathrm{VC}$ & sa-sr & moderate & \\
\hline 3 & 001 & strongly bimodal & $\mathrm{Si}-\mathrm{VF} ; \mathrm{C}-\mathrm{VC}, \mathrm{G}(n=1)$ & sa-sr & moderate & \\
\hline 3 & 002 & weakly bimodal & Si-F; M-G & sa-sr & none & \\
\hline 3 & 003 & strongly bimodal & $\mathrm{Si}-\mathrm{VF} ; \mathrm{M}(n=1), \mathrm{C}-\mathrm{VC}$ & sa-sr & poor & \\
\hline 3 & 004 & strongly bimodal & Si-F; C-VC & sa-sr & poor & \\
\hline 3 & 005 & weakly bimodal & Si-VF; M-VC & sa-sr & moderate & \\
\hline 3 & 006 & strongly bimodal & Si-VF; C-VC & sa-sr & moderate & \\
\hline 3 & 009 & unimodal & $\mathrm{Si}-\mathrm{M}$ & sa-sr & moderate & contains bone fragments \\
\hline 3 & 014 & weakly bimodal & Si-VF; M & sa-sr & poor to moderate & rectilinear voids from leached shell \\
\hline
\end{tabular}

Notes: Particle sizes are silt (si), fine sand (F), medium sand (M), coarse sand (C), very coarse sand (VC), and gravel (G). Particle shapes are angular (a), subangular (sa), subrounded (sr), rounded (r), and well rounded (wr). 
Table 3. Summary of Paste Texture and Body Group Data.

Kitkahahki Town (14RP1): sample \# prefix DCR-

\begin{tabular}{|c|c|c|c|}
\hline Paste Group & $\begin{array}{c}\text { Typical Materials } \\
\text { (Groups 1-3) }\end{array}$ & $\begin{array}{l}\text { Atypical Materials } \\
\text { (Groups 4-6) }\end{array}$ & Total \\
\hline Typical paste texture & $n=9$ & $n=7$ & $n=16$ \\
\hline $\begin{array}{l}\text { - } 10 \%-20 \% \text { silt } \\
\text { - } 5 \% \text { silt }\end{array}$ & $\begin{array}{l}\text { DCR-216, 217, 214, 219, 222, 213, 211, } \\
215,209\end{array}$ & $\begin{array}{l}\text { DCR-208. 221, 230, 234, 235, } \\
229,236\end{array}$ & \\
\hline Atypical paste texture & $n=9$ & $n=5$ & $n=14$ \\
\hline - $20 \%-30 \%$ silt, F-M sand & $\begin{array}{l}\text { DCR-212, 218, 223, 224, 225, 226, } 228 \text {, } \\
231,232\end{array}$ & DCR-207, 227, 210, 220, 233 & \\
\hline Total & $n=18$ & $n=12$ & $n=30$ \\
\hline
\end{tabular}

White Rock site (14JW1): sample \# prefix LWR-

\begin{tabular}{|c|c|c|c|}
\hline Paste Group & $\begin{array}{l}\text { Typical Materials } \\
\text { (Groups 1-3) }\end{array}$ & $\begin{array}{l}\text { Atypical Materials } \\
\text { (Groups 4-6) }\end{array}$ & Total \\
\hline $\begin{array}{l}\text { Typical paste texture } \\
\text { - } 10 \%-20 \% \text { silt }\end{array}$ & $\begin{array}{l}n=11 \\
\text { LWR-007, 008, 013, 001, 002, 003, 004, } \\
005,006,009,014\end{array}$ & - & $n=11$ \\
\hline
\end{tabular}

features and little or no naturally occurring fine to medium sand. This includes pastes in this study with 10\%-20\% silt or less. "Atypical" paste texture is coarser, with 20\%-30\% silt and fine sandmedium sand combined and no visible redoximorphic features. Atypical paste texture may indicate collection of coarser self-tempered clays, not necessarily from the same alluvial settings as the "typical" pastes. We interpret atypical sandier pastes as acceptance of a broader range of raw clays. A similar shift to sandier pastes took place along the Knife River in the Northern Plains, where contemporaneous or later (ca. AD 1782-1837) Hidatsa potters used some pastes with fine to medium sand (Hollenback 2017:Figure 11.4), although sandy pastes are notably absent in earlier (pre-AD 1782) Hidatsa ceramics (Hollenback 2017:Figure 11.3).

Even when Kitkahahki Town potters used typical pastes, unusual features appear. Potters at least occasionally combined sediments with different silt or sand percentages, which can be distinguished petrographically when incompletely mixed (e.g., DCR-215; Figure 4e). This trait has not been observed in precolumbian Plains pottery in this and other petrographic analyses (Beck
2001; Beck and Hannus 2020). It may reflect expedient collection of alluvial pottery clays including multiple depositional lenses and then minimal if any subsequent clay processing.

"Typical" body groups (Groups 1-3) include quartz and feldspar sand and may have subangular-subrounded fragments of sedimentary rock such as sandstone, siltstone, shale, and chert from local outcrops as well as extralocal rock and mineral debris from glaciogenic sediments (e.g., granite/gneiss and micaceous schist). These ceramic inclusions are common after AD 1000 in north-central Kansas and the surrounding region, observed in this study at the White Rock site and more broadly in Central Plains tradition sites (Roper et al. 2010). "Atypical" body groups (Groups 4-6) include crystalline calcite, gypsum, or fossil shell from limestone most likely originating in the Carlile Shale Formation. In north-central Kanas, these inclusions appeared in vessels during the Keith phase of the Plains Woodland period (ca. AD 400-1100; Hoard et al. 2017) but are absent from the later Central Plains tradition and White Rock-phase vessels (Ritterbush 2001, 2006; Roper et al. 2010; Rusco 1960). 
Contact-era Pawnee pottery from Kitkahahki Town often exhibits atypical paste textures, atypical inclusions, or both (see Table 3). These differences appear at a site occupied relatively late in the ceramic senescence process-a process that began after significant threats to and adaptations for Pawnee survival. In the Northern Plains, ceramic changes have been directly linked to epidemic events and the loss of skilled potters (Hollenback 2012, 2017), and the Pawnee in the Central Plains also suffered substantial population losses in epidemics. Pawnee people also made economic shifts and changes to labor allocation that reduced ceramic production throughout the eighteenth century (Beck 2020). To these ongoing challenges to ceramic production, we add safe access (or lack thereof) to traditionally preferred raw materials.

Raw material access constraints may explain the atypical inclusions from the Carlile Shale, which reappeared in late Pawnee pottery after a seven-centuries-long hiatus in the region. This formation is exposed in various areas along the Republican River and its tributaries in the study area (see Figure 3), including an outcropping immediately southeast of Kitkahahki Town. At least one potter from this village limited the area of collection of raw materials to the exposure of this geologic unit adjacent to the village. The historical record suggests a dangerous environment for Pawnee women outside village boundaries in the late eighteenth century, perhaps particularly dangerous around isolated Pawnee villages in the Republican River valley. Potters here would be motivated to use the closest sources of ceramic raw materials, even if the materials were unusual.

\section{Conclusion}

If he could not take their ponies, he intended to try and kill women on the outskirts of the village, take their scalps, and take them home

[Dorsey and Murie 1904:222].

Women's activities in the Great Plains, including ceramic manufacture, were shaped by geological, biological, social, and political dimensions of the region. Unquestionably, they were shaped by tradition and intergenerational knowledge, and by gaps in that knowledge related to epidemic disease. They were shaped by daily needs and tasks, and the larger economic goals of their households and communities. We argue here that for Pawnee women, they were also shaped by heightened levels of regional conflict and threats to women's safety. Violence and raiding were not new to the Central Plains in the late eighteenth century-indeed, both have a long history in North America and throughout the world (e.g., Cameron 2016; Keeley 1996) - but they were elevated enough to markedly constrain women's movements in this setting. Not all tasks outside village boundaries could be avoided (women continued farming and collecting firewood, for example), but ceramic raw material collection was at least occasionally adjusted to reduce risk.

Pawnee ceramic production was already declining by AD 1777, when Kitkahahki Town may have been first occupied (Beck 2020; Grange 1968). Women here did make pottery, however, and through their choice of raw materials, we catch a glimpse of their experiences with a given landscape. Petrographic analysis contributes to our understanding of Indigenous communities in colonized settings, particularly to questions of technological change and landscape use when both were intensely negotiated and rapidly changing.

Acknowledgments. Our work was supported by funding for thin section preparation and petrographic analysis. Costs for Kitkahahki Town (14RP1) ceramics were covered by a 2013 Historic Preservation Fund grant from the Kansas Historical Society to Donna Roper (grant number P13AFQQQ45-Q07). Costs for White Rock site (14JW1) ceramics were covered by an award from the Academic Excellence Fund of Kansas State University to Lauren Ritterbush. We also gratefully acknowledge the efforts of American Antiquity editors Lynn Gamble and Debra Martin and three anonymous reviewers.

Data Availability Statement. All data collected during this research are provided in the manuscript.

\section{References Cited}

Adair, Mary J., and Jack L. Hofman

2021 The Growth of Pawnee Archaeology. In People in a Sea of Grass: Archaeology's Changing Perspective on Indigenous Plains Communities, edited by Matthew E. Hill Jr. and Lauren W. Ritterbush, pp. 98-117. University of Utah Press, Salt Lake City. 
Annis, M. Beatrice

1985 Resistance and Change: Pottery Manufacture in Sardinia. World Archaeology 17:240-255.

Arnold, Dean E.

1988 Ceramic Theory and Cultural Process. Cambridge University Press, Cambridge.

Beck, Margaret E.

2001 Pottery Production at the Mugler Site (14CY1-A), A Central Plains Tradition House in North-Central Kansas. Plains Anthropologist 46:5-20.

2009 Counting Pots in Kalinga, Philippines: Short- and Long-Term Change in Household Assemblages. Ethnoarchaeology 1:79-106.

2020 Pawnee Vessel Function and Ceramic Persistence: Reconstructed Vessels from the Burkett, Barcal, Linwood, Bellwood, and Horse Creek Sites. Plains Anthropologist 65:203-226.

Beck, Margaret E., and L. Adrien Hannus

2020 Middle Mississippian Ceramics in the Northern Hinterlands: Red-Slipped Pottery in Initial Middle Missouri Sites. Plains Anthropologist 65:25-42.

Beck, Margaret E., and Mark A. Neupert

2009 Identifying Pottery Clay from Rice Fields: An Example from Southern Luzon, the Philippines. Journal of Archaeological Science 36:843-849.

Bozell, John R.

1988 Changes in the Role of the Dog in Protohistoric-Historic Pawnee Culture. Plains Anthropologist 33:95-111.

Brooks, James F.

2002 Captives and Cousins: Slavery, Kinship, and Community in the Southwest Borderlands. University of North Carolina Press, Chapel Hill.

Brown, Kaitlin M.

2018 Crafting Identity: Acquisition, Production, Use, and Recycling of Soapstone during the Mission Period in Alta California. American Antiquity 83:244-262.

Bullock, Peter, Nicolas Federoff, A. Jongerius, Georges Stoops, Tina Tursina, and U. Babel

1985 Handbook for Soil Thin Section Description. Waine Research Publications, Albrighton, Wolverhampton, United Kingdom.

Cameron, Catherine M.

2016 Captives: How Stolen People Changed the World. University of Nebraska Press, Lincoln.

Deal, Michael

1998 Pottery Ethnoarchaeology in the Central Maya Highlands. University of Utah Press, Salt Lake City.

DeMallie, Raymond J. (editor)

2001 Handbook of North American Indians, Vol. 13. Smithsonian Institution, Washington, DC.

Dorsey, George A., and James R. Murie

1904 Traditions of the Skidi Pawnee. Houghton, Mifflin, Boston.

Dubin, Lois Sherr

2003 North American Indian Jewelry and Adornment: From Prehistory to the Present. Harry N. Abrams, New York

Echo-Hawk, Roger C.

1992 Pawnee Mortuary Traditions. American Indian Culture and Research Journal 16(2):77-99.

Echo-Hawk, Walter R.

2018 Sea of Grass: A Family Tale from the American Heartland. Fulcrum Publishing, Golden, Colorado.

Ewers, John C.

1997 Plains Indian History and Culture: Essays on Continuity and Change. University of Oklahoma Press, Norman.
Fenn, Elizabeth A.

2001 Pox Americana: The Great Smallpox Epidemic of 1775-82. Hill and Wang, New York.

Ferris, Neal

2009 The Archaeology of Native-Lived Colonialism: Challenging History in the Great Lakes. University of Arizona Press, Tucson.

Graesch, Anthony P., Julienne Bernard, and Anna C. Noah

2010 A Cross-Cultural Study of Colonialism and Indigenous Foodways in Western North America. In Across a Great Divide: Continuity and Change in Native North American Societies, 1400-1900, edited by Laura L. Scheiber and Mark D. Mitchell, pp. 213-238. University of Arizona Press, Tucson.

Grange, Roger T., Jr.

1968 Pawnee and Lower Loup Pottery. Publications in Anthropology No. 3. Nebraska State Historical Society, Lincoln.

Griffitts, Janet L.

2013 Bones, Stones and Metal Tools: Experiments in Middle Missouri Bone Working. In The Archaeology of Hybrid Material Culture, edited by Jeb J. Card, pp. 342-363. Occasional Paper No. 39. Center for Archaeological Investigations, Southern Illinois University, Carbondale.

Habicht-Mauche, Judith A.

2008 Captive Wives? The Role and Status of Nonlocal Women on the Protohistoric Southern High Plains. In Invisible Citizens: Captives and Their Consequences, edited by Catherine M. Cameron, pp. 181-204. University of Utah Press, Salt Lake City.

Hattin, Donald E.

1962 Stratigraphy of the Carlile Shale (Upper Cretaceous) in Kansas. State Geological Survey of Kansas Bulletin 156. University of Kansas, Lawrence.

Hoard, Robert J., John R. Bozell, and Gina S. Powell

2017 The Kraus 1 Site, 14EL313: A Keith Phase Component in West Central Kansas. Report by the Cultural Resources Division, Kansas Historical Society, Topeka.

Hollenback, Kacy L.

2012 Disaster, Technology, and Community: Measuring Responses to Smallpox Epidemics in Historic Hidatsa Villages, North Dakota. PhD dissertation, School of Anthropology, University of Arizona, Tucson.

2015 Technological Continuity and Change PostDisaster: A Behavioral Model. In Explorations in Behavioral Archaeology, edited by William H. Walker and James Skibo, pp. 500-534. University of Utah Press, Salt Lake City.

2017 Petrography and Behavior When the Minerals Do Not Change: Textural Analysis of Disaster Impacts on Historic Hidatsa Potting Practices, North Dakota. In Integrative Approaches in Ceramic Petrography, edited by Mary F. Ownby, Isabelle C. Druc, and Maria A. Masucci, pp. 157-176. University of Utah Press, Salt Lake City.

Hollenback, Kacy L., and Michael B. Schiffer

2010 Technology and Material Life. In The Oxford Handbook of Material Culture Studies, edited by Dan Hicks and Mary C. Beaudry, pp. 313-332. Oxford University Press, Oxford.

Hudson, LuAnn

1993 Protohistoric Pawnee Lithic Economy. Plains Anthropologist 38:265-277.

Hyde, George E.

1974 The Pawnee Indians. University of Oklahoma Press, Norman. 
Irving, Washington

1956 A Tour on the Prairies. University of Oklahoma Press, Norman.

Jensen, Richard E. (editor)

2010 The Pawnee Mission Letters, 1834-1851. University of Nebraska Press, Lincoln.

John, Elizabeth A. H.

1981 Storms Brewed in Other Men's Worlds: The Confrontation of Indians, Spanish, and French in the Southwest, 1540-1795. University of Nebraska Press, Lincoln.

Johnson, Craig M.

1998 The Coalescent Tradition. In Archaeology on the Great Plains, edited by W. Raymond Wood, pp. 308 344. University Press of Kansas, Lawrence.

Josephs, Richard L.

2005a Applying Micromorphological Terminology to Ceramic Petrography. Geoarchaeology 20:861-865.

2005b A Petrographic Analysis of Extended Middle Missouri Ceramics from North Dakota. Plains Anthropologist 50:111-119.

2011 A Petrographic Analysis of Glenwood Locality Ceramics, Mills County, Iowa. Central Plains Archeology 13:1-19.

Keeley, Lawrence $\mathrm{H}$.

1996 War before Civilization: The Myth of the Peaceful Savage. Oxford University Press, Oxford.

Kehoe, Alice Beck

2013 "Slaves" and Slave Raiding on the Northern Plains and Rupert's Land. In Human Expeditions: Inspired by Bruce Trigger, edited by Stephen Chrisomalis and André Costopoulos, pp. 31-40. University of Toronto Press, Toronto

Kessler, Nicholas V., Gregory W. L. Hodgins, Michael C. Stambaugh, and Mary J. Adair

2021 Tree-Ring-Radiocarbon Dating at a Late Contact Period Kitkahahki Pawnee Site on the Central Great Plains, USA. Radiocarbon 63:481-497.

Krause, Richard A.

1972 The Leavenworth Site: Archaeology of an Historic Arikara Community. University of Kansas, Lawrence.

Krause, Richard A., and Kacy L. Hollenback

2016 A Brief Context-Dependent Study of Arikara Ceramic Change. Plains Anthropologist 61:392-409.

Law Pezzarossi, Heather

2014 Assembling Indigeneity: Rethinking Innovation, Tradition and Indigenous Materiality in a 19th-Century Native Toolkit. Journal of Social Archaeology 14:340-360.

Liebmann, Matthew J.

2017 From Landscapes of Meaning to Landscapes of Signification in the American Southwest. American Antiquity 82:642-661.

Logan, Brad

1995 Phasing in White Rock: Archaeological Investigation of the White Rock and Warne Sites, Lovewell Reservoir, Jewell County, Kansas, 1994-1995. Report prepared by the Museum of Anthropology, University of Kansas, Lawrence, for the Nebraska-Kansas Area Office, Bureau of Reclamation, Grand Island, Nebraska.

1998 Oneota Far West: The White Rock Phase. Wisconsin Archeologist 79(2):248-267.

2010a A Matter of Time: The Temporal Relationship of Oneota and Central Plains Traditions. Plains Anthropologist 55:277-292.

2010b Archaeological Investigations at the White Rock (14JW1) and Bergstrom (14JW17) Sites, Lovewell Reservoir, 2009. Report prepared by the Department of
Sociology, Anthropology, and Social Work, Kansas State University, Manhattan, for the Nebraska-Kansas Area Office, Bureau of Reclamation, Grand Island, Nebraska.

Logan, Brad, and William E. Banks

1994 White Rock Revised: Archaeological Investigation of the White Rock and Warne Sites, Lovewell Reservoir Kansas, 1993. Report to Bureau of Reclamation, Nebraska-Kansas Area Office. Project Report Series 85, Museum of Anthropology, University of Kansas, Lawrence.

Lowie, Robert $\mathrm{H}$

1982 Indians of the Plains. University of Nebraska Press, Lincoln.

Martelle, Holly

2004 Some Thoughts on the Impact of Epidemic Disease and European Contact on Ceramic Production in Seventeenth Century Huronia. Ontario Archaeology 7778:22-44.

Melton, Mallory A.

2018 Cropping in an Age of Captive Taking: Exploring Evidence for Uncertainty and Food Insecurity in the Seventeenth-Century North Carolina Piedmont. American Antiquity 83:204-223.

Neupert, Mark A.

1999 Potters and Politics: Factionalism and the Organization of Ceramic Production in Paradijon, the Philippines. PhD dissertation, School of Anthropology, University of Arizona, Tucson.

O'Connor, Howard G.

2005 Cretaceous System. In The Stratigraphic Succession in Kansas, edited by Doris E. Zeller with contributions by John M. Jewett, Charles K. Bayne, Edwin D. Goebel, Howard G. O'Connor, Ada Swineford, and Doris E. Zeller. Originally published in 1968 as Kansas Geological Survey Bulletin 189. Web version (2005), http:/ www.kgs.ku.edu/Publications/Bulletins/189/index.html, accessed July 1, 2020.

O'Shea, John M.

1989 Pawnee Archaeology. Central Plains Archaeology 1:49-107.

Parks, Douglas R., and Waldo R. Wedel

1985 Pawnee Geography Historical And Sacred. Great Plains Quarterly 5:143-176.

Quinn, Patrick Sean

2013 Ceramic Petrography: The Interpretation of Archaeological Pottery and Related Artefacts in Thin Section. Archaeopress, Oxford.

Ritterbush, Lauren W.

2001 Temper in White Rock Site Ceramics. Current Archaeology in Kansas 2:7-14.

2002 Leary Site Revisited: Oneota and Central Plains Tradition Occupation along the Lower Missouri. Plains Anthropologist 47:249-262.

2006 Late Prehistoric Oneota in the Central Plains. In Kansas Archaeology, edited by Robert J. Hoard and William E. Banks, pp. 151-164. University Press of Kansas, Lawrence.

2011 The Phil Site (14JW48) and the Central Plains Tradition at Lovewell Reservoir, Jewell County, Kansas: Ceramic Analysis. Kansas Anthropologist 32:70-86.

2021 Configuring Late Prehistory in the Central Plains. In People in a Sea of Grass: Archaeology's Changing Perspective on Indigenous Plains Communities, edited by Matthew E. Hill Jr. and Lauren W. Ritterbush, pp. 32-52. University of Utah Press, Salt Lake City. 
Ritterbush, Lauren W., and Kendra B. Kobiskie

2007 Ceramics. In Windmill Creek: National Register of Historic Places Evaluation of a Central Plains Tradition House Site, Lovewell Reservoir, Jewell County, Kansas-2006, by Brad Logan. Report prepared by the Department of Sociology, Anthropology, and Social Work, Kansas State University, Manhattan, Kansas, for the Nebraska-Kansas Area Office, Great Plains Region, Bureau of Reclamation, Grand Island, Nebraska.

Ritterbush, Lauren W., and Brad Logan

2000 Late Prehistoric Oneota Population Movement into the Central Plains. Plains Anthropologist 45:257-272.

Rogers, J. Daniel

1990 Objects of Change: The Archaeology and History of Arikara Contact with Europeans. Smithsonian Institution, Washington, DC.

Roper, Donna C.

1991 John Dunbar's Journal of the 1834-5 Chawi Winter Hunt and Its Implications for Pawnee Archaeology. Plains Anthropologist 36:193-214.

2006a The Pawnee in Kansas: Ethnohistory and Archaeology. In Kansas Archaeology, edited by Robert J. Hoard and William E. Banks, pp. 233-247. University Press of Kansas, Lawrence.

2006b The Central Plains Tradition. In Kansas Archaeology, edited by Robert J. Hoard and William E. Banks, pp. 105-132. University Press of Kansas, Lawrence.

2015 The Archaeology of Central Kansas: Based on the Reed Collections from Archaeological Sites in Saline and Ottawa Counties. Bulletin No. 3. Kansas Anthropological Association, Topeka.

Roper, Donna C., Richard L. Josephs, and Margaret E. Beck

2010 Determining Provenance of Shell-Tempered Pottery from the Central Plains Using Petrography and Oxidation Analysis. American Antiquity 75:134-157.

Rusco, Mary K.

1960 The White Rock Aspect. Notebook 4. Laboratory of Anthropology, University of Nebraska, Lincoln.

Sargent, Carolyn F., and David A. Friedel

1986 From Clay to Metal: Culture Change and Container Usage among the Bariba of Northern Bénin, West Africa. African Archaeological Review 4:177-195.

Scheiber, Laura L., and Judson Byrd Finley

2010 Mountain Shoshone Technological Transitions across the Great Divide. In Across a Great Divide: Continuity and Change in Native North American Societies, 1400-1900, edited by Laura L. Scheiber and Mark D. Mitchell, pp. 128-148. University of Arizona Press, Tucson.

Stoltman, James B.

1989 A Quantitative Approach to the Petrographic Analysis of Ceramic Thin Sections. American Antiquity 54:147-160.

1991 Ceramic Petrography as a Technique for Documenting Cultural Interaction: An Example from the Upper Mississippi Valley. American Antiquity 56:103-120.

Stoltman, James B., and Joseph A. Tiffany

2016 Using Ceramic Petrography to Evaluate the Nature of Cultural Interaction between the Spoon River Culture of the Central Illinois River Valley and the Mill Creek Culture of Northwest Iowa. Journal of the Iowa Archaeological Society 63:21-43.

Stoops, Georges

2003 Guidelines for Analysis and Description of Soil and Regolith Thin Sections. Soil Science Society of America, Madison, Wisconsin.

Strong, William Duncan

1935 An Introduction to Nebraska Archeology. Smithsonian Miscellaneous Collections Vol. 93, No. 10. Smithsonian Institution, Washington, DC.

Sundstrom, Linea

1997 Smallpox Used Them Up: References to Epidemic Disease in Northern Plains Winter Counts, 1714-1920. Ethnohistory 44:305-342.

2002 Steel Awls for Stone Age Plainswomen: Rock Art, Religion, and the Hide Trade on the Northern Plains. Plains Anthropologist 47:99-119.

Trimble, Michael K.

1989 Infectious Disease and the Northern Plains Horticulturists: A Human Behavior Model. Plains Anthropologist 34:41-59.

van de Logt, Mark

2016 "I Was Brought to Life to Save My People from Starvation and from Their Enemies": Pahukatawa and the Pawnee Trauma of Genocide. American Indian Culture and Research Journal 40(3):23-46.

Vehik, Susan C.

1989 Problems and Potential in Plains Indian Demography. Plains Anthropologist 34: 115-125.

Wagner, Mark J.

2010 The Archaeology of Nativism among the Nineteenth-Century Algonquin Peoples of Illinois. In Across a Great Divide: Continuity and Change in Native North American Societies, 1400-1900, edited by Laura L. Scheiber and Mark D. Mitchell, pp. 107-127. University of Arizona Press, Tucson.

Wedel, Waldo R.

1936 An Introduction to Pawnee Archeology. Bureau of American Ethnology Bulletin 112. Smithsonian Institution, Washington, DC.

1986 Central Plains Prehistory: Holocene Environments and Culture Change in the Republican River Basin. University of Nebraska Press, Lincoln.

Weltfish, Gene

1971 The Lost Universe: Pawnee Life and Culture. Ballantine Books, New York.

White, Richard

1978 The Winning of the West: The Expansion of the Western Sioux in the Eighteenth and Nineteenth Centuries. Journal of American History 65:319-343.

Wilson, Frank

1984 Landscapes: A Geologic Diary. In Kansas Geology: An Introduction to Landscapes, Rocks, Minerals, and Fossils, edited by Rex Buchanan, pp. 9-39. University Press of Kansas, Lawrence.

Submitted September 25, 2020; Revised August 20, 2021; Accepted August 24, 2021 